\title{
Analisis Penerapan Pengakuan Pendapatan PSAK72 dan Dampak terhadap Pajak Penghasilan Final dan Manajemen Laba pada Perusahaan Kontruksi yang Terdaftar di Bursa Efek Indonesia Tahun 2019.
}

\author{
Monica Adella \\ Program Studi Sarjana Akuntansi Bisnis, Sekolah Tinggi Manajemen PPM \\ Jl. Menteng Raya No. 9 - 19, Menteng, DKI Jakarta, Indonesia \\ momonicadella@gmail.com

\section{Novy Silvia Dewi*} \\ Program Studi Sarjana Akuntansi Bisnis, Sekolah Tinggi Manajemen PPM \\ Jl. Menteng Raya No. 9 - 19, Menteng, DKI Jakarta, Indonesia \\ novy.silviadewi.nsd@gmail.com
}

\author{
Ahalik \\ Program Studi Sarjana Akuntansi Bisnis, Sekolah Tinggi Manajemen PPM \\ Jl. Menteng Raya No. 9 - 19, Menteng, DKI Jakarta, Indonesia \\ ahalikcpa@gmail.com
}

Diterima: 29-03-2021 | Disetujui: 07-07-2021 ｜ Dipublikasi: 31-07-2021

This work is licensed under a Creative Commons Attribution 4.0 International License.

\begin{abstract}
ABSTRAK
Penelitian ini bertujuan untuk mengetahui bagaimana dampak penerapan PSAK 72 pada perusahaan konstruksi yang terdaftar di Bursa Efek Indonesia dengan asumsi perusahaan melakukan penerapan dini PSAK 72 pada laporan keuangan tahun 2019. PSAK 72 merupakan standar yang ditetapkan oleh IAI mengenai pengakuan dan pengukuran kontrak dengan pelanggan yang berlaku efektif pada tanggal 1 Januari 2020. Metode penelitian yang digunakan adalah metode deskriptif kualitatif dengan membandingkan penerapan PSAK 34 dan PSAK 44 dengan PSAK 72 pada perusahaan konstruksi. Hasil penelitian ini menunjukkan bahwa penerapan PSAK 72 tidak berdampak pada kontrak konstruksi tetapi berdampak pada kontrak real estate. Kontrak real estate harus mengakui pendapatan pada suatu waktu berdasarkan PSAK 72. Kontrak real estate dalam PSAK 72 dan pajak penghasilan memiliki perbedaan dalam pengakuan pendapatan dan pengenaan pajak. Penurunan pendapatan disebabkan pengakuan pendapatan real estate mendorong manajemen untuk melakukan manajemen laba.
\end{abstract}

Kata Kunci:

PSAK72; Pengakuan Pendapatan; Pengukuran Pendapatan; Perusahaan Konstruksi.

\begin{abstract}
This study aims to determine how the impact of the application of PSAK 72 in construction companies listed in Indonesia Stock Exchange with the assumption that the company did early adoption of PSAK 72 in the 2019 financial statements. PSAK 72 is a standard set by IAI regarding the recognition and measurement of contracts with customers effectively valid on January 1, 2020. The research method used is a qualitative descriptive method by comparing the application of PSAK 34 and PSAK 44 with PSAK 72 in construction companies. Results of this research indicate that the application of PSAK 72 does not have an impact on construction contract but have an impact on real estate contract. Real estate contract must recognition revenue at point in time based on PSAK 72. Real estate contract in PSAK 72 and income tax have difference in revenue recognition and tax imposition. Decreased revenue caused of real estate revenue recognition push management to do earnings management.
\end{abstract}

Keywords:

PSAK72; Revenue Recognition; Revenue Measurement; Construction Companies 


\section{PENDAHULUAN}

IFRS mengatur standar akuntansi sebagai seperangkat prinsip yang diikuti perusahaan ketika menyiapkan dan mempublikasikan laporan keuangan untuk menggambarkan kinerja keuangan perusahaan secara ter standarisasi. Tujuan IASB mengembangkan Standar IFRS untuk membuat sebuah standar umum laporan keuangan yang berlaku di berbagai dunia dengan menjunjung tinggi nilai transparansi, akuntabilitas, dan efisiensi. Standar umum dibutuhkan untuk mendukung ekonomi modern yang bergantung pada transaksi antar negara seperti investor asing, perusahaan yang mencari pendanaan, untuk melakukan transaksi, atau memiliki operasi internasional.

Sebagai negara yang mengadopsi IFRS sebagai standar laporan keuangan, DSAK IAI mengonvergen IFRS 15 "Revenue from Customer Contract" menjadi PSAK72: Pendapatan dari Kontrak Pelanggan. PSAK72 diberlakukan secara efektif mulai tanggal 1 Januari 2020 dengan opsi penerapan dini, artinya setiap perusahaan dibolehkan jika ingin mengimplementasikan PSAK72 sebelum tanggal efektif (Ikatan Akuntan Indonesia, 2020). PSAK72 ini akan menjadi standar tunggal yang mengatur mengenai pengakuan pendapatan dan secara resmi menggantikan seluruh standar yang terkait dengan pengakuan pendapatan yang ada saat ini, yaitu PSAK 23 mengenai Pendapatan, PSAK34 mengenai Kontrak Konstruksi, PSAK44 mengenai Akuntansi Aktivitas Pengembangan Real estate, ISAK 10 mengenai Program Loyalitas Pelanggan, ISAK 21 mengenai Perjanjian Konstruksi Real estate, dan ISAK 27 mengenai Pengalihan Aset dari Pelanggan (Ikatan Akuntan Indonesia, 2020).

PSAK72 merupakan standar tunggal dalam mengakui dan mengukur pendapatan perusahaan yang berlaku bagi seluruh entitas di berbagai industri. "Big Four" yang terdiri dari Akuntan Publik terbesar di dunia telah mengeluarkan pernyataan bagaimana pengaruh IFRS 15 dengan kualitas laporan keuangan. Industri yang terpengaruh secara signifikan menurut Big Four yaitu, sektor telekomunikasi, bangunan dan konstruksi, dan ritel dan barang konsumsi.

Pernyataan tersebut dapat digunakan untuk memprediksi industri sektor apa saja yang akan terpengaruh dengan diberlakukannya PSAK 72 sebagai standar yang mengadopsi IFRS 15. KPMG menyatakan bahwa IFRS 15 menimbulkan kekhawatiran bagi sektor konstruksi, karena kemampuan untuk mengakui pendapatan dari sektor konstruksi secara progresif dapat dikurangi atau dihilangkan. Industri konstruksi merupakan salah satu sektor industri yang terpengaruh dengan penerapan PSAK 72 karena menghapus PSAK 34 tentang Kontrak Konstruksi dan PSAK 44 tentang Akuntansi Aktivitas Pengembangan Real estate yang selama ini digunakan sebagai standar pendapatan.

Pembangunan infrastruktur dalam kurun waktu tahun 2015 - 2020 mengalami peningkatan (Jayani, 2019). Peningkatan tersebut ditandai dengan penaikan anggaran infrastruktur dalam RAPBN tahun 2020 sebesar 4,9\% menjadi Rp 419,2 triliun. Sasaran pembangunan infrastruktur terbagi dalam bidang berdasarkan fungsi dari infrastruktur yang dibangun. Bidang - bidang tersebut meliputi bidang prasarana, bidang ketahanan air, dan bidang perumahan. Peningkatan infrastruktur dengan bidang yang spesifik membuat kebutuhan industri konstruksi semakin meningkat. Industri konstruksi yang didominasi oleh Badan Usaha Milik Negara (BUMN) berdampak secara langsung dengan peningkatan 
Adella, M., Dewi, N.S., \& Ahalik, A. (2021). Analisis Penerapan Pengakuan Pendapatan ....

infrastruktur yang didanai dengan APBN. Dengan peningkatan APBN tersebut dapat diperkirakan bahwa pendapatan pada industri konstruksi dapat meningkat juga.

Tabel 1. IFRS 15 dan dampak terhadap kualitas laporan keuangan

\begin{tabular}{|c|c|c|c|c|}
\hline Sector & KPMG $^{\mathbf{a})}$ & $\mathbf{E Y}^{\mathbf{b})}$ & Deloitte $^{\mathrm{c})}$ & PWC $^{d)}$ \\
\hline Insurance & Medium & Medium/Low & $N / A$ & $N / A$ \\
\hline Building and Construction & Medium & Medium/High & Medium & Medium \\
\hline Retail and consumer goods & Medium & Medium & Medium & Medium \\
\hline Licensors* & Medium/high & $N / A$ & Medium & Medium \\
\hline Real estate & Medium & $N / A$ & Medium & Medium \\
\hline Technology & Medium & $N / A$ & Medium/Low & High \\
\hline Telecommunication & High & High & High & High \\
\hline Energy (mining, oil and gas) & Medium & Medium & Low & Low \\
\hline Transport & Medium & N/A & $N / A$ & Low \\
\hline \multicolumn{5}{|c|}{$\begin{array}{l}\text { a) KPMG (2015, May), "Revenue - Issues in depth", available at www.kpmg.com } \\
\text { b) Ernst and Young (2016, April), "Revenue from contracts with customers, A summary of IFRS } 15 \text { and its effects", } \\
\text { available at www.ey.com } \\
\text { c) In this case papers of each sector were analyzed and at the relative judgment was taken from the analysis of } \\
\text { each. The key element to arrive at the aforesaid judgment was the level of risk of error associated with the steps of } \\
\text { the IFRS } 15 \text { model } \\
\text { d) PriceWaterhouseCoopers (2014, June), "IFRS 15, implentation challenges", available at from www.pwc.com } \\
\text { *media, life science, franchisors }\end{array}$} \\
\hline
\end{tabular}

Sumber: Marco Tunito, 2019

Industri konstruksi merupakan salah satu sektor industri yang terpengaruh dengan penerapan PSAK 72 karena menghapus PSAK 34 tentang Kontrak Konstruksi dan PSAK 44 tentang Akuntansi Aktivitas Pengembangan Real estate yang selama ini digunakan sebagai standar pendapatan. Peningkatan pendapatan BUMN melalui peningkatan RAPBN setiap tahunnya untuk anggaran konstruksi menimbulkan kekhawatiran dalam mengakui pendapatan yang telah berubah ke PSAK 72 . Kekhawatiran tersebutlah yang harus diteliti apakah PSAK 72 dapat berdampak serupa atau masih ada pilihan lain dalam sektor konstruksi BUMN dalam mengakui pendapatan.

Dampak terhadap pendapatan akan mengakibatkan efek secara langsung kepada pajak penghasilan. Ketentuan pajak penghasilan yang dikenakan oleh perusahaan diperhitungkan sesuai dengan pendapatan yang diakui sesuai dengan standar pajak penghasilan sebelumnya. Dengan adanya PSAK 72, pajak penghasilan yang dibayarkan harus juga mengikuti standar baru tersebut. Berdasarkan penjabaran tersebut, penelitian ini mengacu pada penelitian sebelumnya dengan tema analisis dampak penerapan PSAK 72 terhadap kinerja keuangan perusahaan real estate di Indonesia yang terdaftar di BEI tahun 2018.

Penelitian ini bertujuan untuk mengetahui bagaimana dampak penerapan pengakuan dan pengukuran pendapatan PSAK 72 pada perusahaan konstruksi. Kemudian penelitian ini juga untuk mengetahui bagaimana dampak penerapan PSAK 72 terhadap pajak penghasilan final dan manajemen laba pada perusahaan konstruksi.

\section{PSAK34: Kontrak Konstruksi 2010 (Penyesuaian 2014)}

PSAK34 digunakan untuk mengatur perlakuan akuntansi yang berhubungan dengan kontrak konstruksi. Kontrak konstruksi merupakan kontrak yang terbentuk dari hasil negosiasi secara khusus untuk mengonstruksikan suatu aset atau kombinasi aset yang berhubungan erat satu sama lain atau 
saling tergantung dalam hal rancangan, teknologi, dan fungsi atau tujuan pokok penggunaan berdasarkan PSAK34 paragraf 03 (Ikatan Akuntan Indonesia, 2018). Kontrak konstruksi berdasarkan PSAK34 paragraf 05 meliputi, kontrak pemberian jasa yang berhubungan langsung dengan konstruksi aset, sebagai contoh, pelayanan jasa untuk manajer proyek dan arsitek; dan kontrak untuk penghancuran atau restorasi aset dan restorasi lingkungan setelah penghancuran aset (Ikatan Akuntan Indonesia, 2018). Pendapatan kontrak berdasarkan PSAK34 paragraf 11 terdiri dari, jumlah pendapatan semula yang disetujui dalam kontrak; dan penyimpangan dalam pekerjaan kontrak, klaim, dan pembayaran insentif (Ikatan Akuntan Indonesia, 2018).

Pengukuran pendapatan dinyatakan dalam PSAK34 paragraf 12, yaitu pendapatan kontrak diukur pada nilai wajar dari imbalan yang diterima atau akan diterima. Pengukuran dipengaruhi oleh ketidakpastian di masa mendatang. Estimasi perlu direvisi sesuai dengan realisasi dan ketidakpastian di masa mendatang. Ketidakpastian tersebut dapat disebabkan oleh penyimpangan yang meningkatkan pendapatan, kenaikan biaya, denda keterlambatan, dan kenaikan jumlah unit (Ikatan Akuntan Indonesia, 2018).

Jika hasil kontrak konstruksi dapat diestimasi secara andal, maka pendapatan kontrak dan biaya kontrak yang berhubungan dengan kontrak konstruksi tersebut diakui masing-masing sebagai pendapatan dan beban kontrak dengan memperhatikan tahap penyelesaian aktivitas kontrak pada tanggal akhir periode pelaporan berdasarkan PSAK34 paragraf 22 (Ikatan Akuntan Indonesia, 2018). Pengakuan pendapatan dan beban dengan memperhatikan tahap penyelesaian suatu kontrak sering menggunakan metode persentase penyelesaian berdasarkan PSAK34 paragraf 25 (Ikatan Akuntan Indonesia, 2018). Pendapatan kontrak dan biaya kontrak diakui sebagai pendapatan dan beban kontrak dalam laporan laba rugi pada periode akuntansi di mana pekerjaan dilakukan berdasarkan PSAK34 paragraf 26 (Ikatan Akuntan Indonesia, 2018). Entitas menggunakan metode yang mengukur secara andal pekerjaan yang dilakukan berdasarkan PSAK34 paragraf 30 (Ikatan Akuntan Indonesia, 2018).

\section{PSAK44: Akuntansi Aktivitas Pengembangan Real estate (1997)}

PSAK44 paragraf 02 diterapkan untuk perusahaan yang bergerak dalam sektor pengembangan real estate, walaupun aktivitas pengembangan real estate tersebut bukan aktivitas utama perusahaan (Ikatan Akuntan Indonesia, 2018). Pernyataan ini berlaku bagi setiap laporan keuangan perusahaan yang melakukan aktivitas pengembangan real estate berdasarkan PSAK44 paragraf 03 (Ikatan Akuntan Indonesia, 2018). Penjualan bangunan rumah, ruko, bangunan sejenis lainnya beserta kaveling tanahnya diakui dengan metode akrual penuh (full accrual method) apabila seluruh kriteria berikut berdasarkan PSAK44 paragraf 06, yaitu proses penjualan telah selesai, harga jual akan tertagih, tagihan penjual tidak akan bersifat subordinasi di masa yang akan datang terhadap pinjaman lain yang akan diperoleh pembeli, dan penjual telah mengendalikan risiko dan manfaat kepemilikan tersebut (Ikatan Akuntan Indonesia, 2018). Pendapatan penjualan unit bangunan kondominium, apartemen, perkantoran, pusat perbelanjaan dan bangunan sejenis lainnya, serta unit dalam kepemilikan time sharing, diakui dengan 
metode persentase penyelesaian (percentage-of-completion method) apabila seluruh kriteria ini terpenuhi berdasarkan PSAK44 paragraf 26, yaitu proses konstruksi telah melampaui tahap awal, yaitu fondasi bangunan telah selesai dan semua persyaratan untuk memulai pembangunan telah terpenuhi, jumlah pembayaran oleh pembeli telah mencapai $20 \%$ dari harga jual yang telah disepakati dan jumlah tersebut tidak dapat diminta kembali oleh pembeli, dan jumlah pendapatan penjualan dan biaya unit bangunan dapat diestimasi dengan andal (Ikatan Akuntan Indonesia, 2018).

Pendapatan penjualan kaveling tanah tanpa bangunan, diakui dengan menggunakan metode akrual penuh (full accrual method) pada saat terjadinya pengikatan jual beli dengan syarat seluruh kriteria sebagai berikut terpenuhi berdasarkan PSAK44 paragraf 33, yaitu jumlah pembayaran oleh pembeli telah mencapai $20 \%$ dari harga jual yang disepakati dan jumlah tersebut tidak dapat diminta kembali oleh pembeli, harga jual akan tertagih, tagihan penjual tidak subordinasi terhadap pinjaman lain yang akan diperoleh pembeli di masa yang akan datang, dan proses pengembangan tanah telah selesai sehingga penjual tidak berkewajiban lagi untuk menyelesaikan kaveling tanah yang dijual, seperti kewajiban untuk mematangkan kaveling tanah atau kewajiban untuk membangun fasilitasfasilitas pokok yang dijanjikan oleh atau yang menjadi kewajiban penjual, sesuai dengan pengikatan jual beli atau ketentuan peraturan perundang-undangan, dan hanya kaveling tanah saja yang dijual, tanpa diwajibkan keterlibatan penjual dalam pendirian bangunan di atas kaveling tanah tersebut (Ikatan Akuntan Indonesia, 2018).

\section{PSAK72: Kontrak dari Pelanggan (2017)}

Terbentuknya PSAK72 memiliki tujuan untuk menetapkan prinsip tentang sifat, jumlah, waktu, dan ketidakpastian pendapatan dan arus kas yang timbul dari kontrak dengan pelanggan. PSAK72 merupakan standar tunggal dari pendapatan, di mana seluruh kontrak dengan pelanggan akan diterapkan sesuai dengan lima model tahap untuk menentukan pengakuan dan pengukuran pendapatan. Lima tahap tersebut akan diimplementasikan ke pendapatan yang PSAK sudah digantikan oleh standar tunggal PSAK72.

Tahap pertama yaitu identifikasi kontrak dengan pelanggan. Kontrak merupakan perjanjian antara dua pihak atau lebih yang menimbulkan hak dan kewajiban yang dapat dipaksakan berdasarkan PSAK72 paragraf 10 (Ikatan Akuntan Indonesia, 2018). Kontrak dapat tertulis, lisan atau tersirat dalam praktik bisnis umum entitas berdasarkan PSAK72 paragraf 10 (Ikatan Akuntan Indonesia, 2018). Kontrak juga harus memenuhi lima ketentuan yang tertera pada PSAK 72 paragraf 09. Kontrak sering digabungkan satu sama lain. Persyaratan baru dari PSAK72, memungkinkan entitas harus menyesuaikan praktik dalam hal kombinasi kontrak. Entitas mengombinasikan dua atau lebih kontrak yang disepakati pada waktu yang sama (atau pihak berelasi dari pelanggan) dan mencatat kontrak tersebut sebagai kontrak tunggal jika satu atau lebih kriteria dalam PSAK72 paragraf 17 terpenuhi.

Tahap kedua yaitu mengidentifikasi kewajiban pelaksanaan. Mengidentifikasi sebagai kewajiban pelaksanaan setiap janji untuk mengalihkan kepada pelanggan baik sesuai dengan PSAK 72 
paragraf 22. Namun sebelumnya perlu diketahui sifat barang atau jasa yang dijanjikan kepada pelanggan dapat dibedakan jika kedua kriteria dalam PSAK72 paragraf 27 terpenuhi. Jika barang atau jasa yang dijanjikan bersifat tidak dapat dibedakan, entitas mengombinasikan barang atau jasa dengan barang atau jasa lain yang dijanjikan sampai entitas mengidentifikasi sepaket barang atau jasa tersebut bersifat dapat dibedakan berdasarkan PSAK72 paragraf 30 (Ikatan Akuntan Indonesia, 2018).

Tahap ketiga yaitu penyelesaian kewajiban pelaksanaan. Pada awal kontrak entitas menentukan apakah entitas menyelesaikan kewajiban pelaksanaan yang diselesaikan dengan dua metode, yaitu penyelesaian sepanjang waktu dan penyelesaian pada waktu tertentu. Entitas mengalihkan pengendalian barang atau jasa sepanjang waktu menyelesaikan kewajiban pelaksanaan dan memenuhi kewajiban pelaksanaan dan mengakui pendapatan sepanjang waktu, jika satu dari kriteria PSAK72 paragraf 35. Jika tidak terpenuhi maka diselesaikan pada waktu tertentu. Pada setiap akhir periode pelaporan, entitas mengukur kembali kemajuan terhadap penyelesaian kewajiban pelaksanaan secara penuh yang diselesaikan sepanjang waktu berdasarkan PSAK72 paragraf 40 (Ikatan Akuntan Indonesia, 2018). Metode pengukuran kemajuan dapat menggunakan dua metode, yaitu metode output dan input.

Tahap keempat yaitu menentukan harga transaksi. Menentukan harga transaksi didapatkan dari jumlah imbalan yang diperkirakan menjadi hak entitas dalam pertukaran untuk mengalihkan barang atau jasa kepada pelanggan, tidak termasuk jumlah yang ditagih atas nama pihak ketiga (contoh: pajak penjualan) berdasarkan PSAK72 paragraf 47 (Ikatan Akuntan Indonesia, 2018). Imbalan yang dijanjikan dalam kontrak dengan pelanggan dapat mencakup jumlah tetap, jumlah variabel, atau keduanya berdasarkan PSAK72 paragraf 47 (Ikatan Akuntan Indonesia, 2018). Sifat, waktu, dan jumlah imbalan yang dijanjikan oleh pelanggan mempengaruhi estimasi harga transaksi dan entitas mempertimbangkan dampak dari estimasi imbalan variabel, time value of money, imbalan non kas, dan utang imbalan berdasarkan PSAK72 paragraf 48 (Ikatan Akuntan Indonesia, 2018).

Tahap keempat yaitu mengalokasikan harga transaksi terhadap kewajiban pelaksanaan. Tujuan mengalokasikan harga transaksi adalah entitas mengalokasikan harga transaksi terhadap setiap kewajiban pelaksanaan (atau barang atau jasa bersifat dapat dibedakan) dalam jumlah yang menggambarkan jumlah imbalan yang diharapkan menjadi hak entitas dalam pertukaran untuk mengalihkan barang atau jasa yang dijanjikan kepada pelanggan berdasarkan PSAK72 paragraf 73 (Ikatan Akuntan Indonesia, 2018). Harga jual berdiri sendiri adalah harga barang atau jasa yang dijanjikan untuk dijual secara terpisah dan mendasari setiap kewajiban pelaksanaan untuk mengalokasikan harga transaksi secara proporsi berdasarkan PSAK72 paragraf 76-77 (Ikatan Akuntan Indonesia, 2018).

\section{Pajak Penghasilan dalam Industri Konstruksi dan Real estate}

Pajak Penghasilan yang memiliki kriteria langsung dalam industri konstruksi terdapat dalam pajak, yaitu Pajak Penghasilan Pasal 4 ayat 2 (PPh 4(2)) dan Pajak Penghasilan Pasal 23 (PPh 23). PPh 4(2) merupakan pajak yang berlaku sekali pada objek tertentu, sehingga objek tersebut tidak dapat 
dikenakan pajak lagi. PPh 23 adalah pajak penghasilan yang berasal dari imbalan atas pekerjaan yang sehubungan dengan jasa teknik, jasa manajemen, jasa konstruksi, jasa konsultan, dan jasa lain selain jasa yang telah dipotong PPh sebagaimana dimaksud dalam Pasal 21. Untuk mempermudah perpajakan bagi industri konstruksi dan real estate, pemerintah mengeluarkan peraturan pemerintah yang mengatur khusus pajak penghasilan final atas jasa konstruksi dan penjualan bangunan dan/atau tanah.

\section{Manajemen Laba}

Konsep teori keagenan merupakan hubungan antara penyedia informasi akuntansi dengan pengguna informasi akuntansi (Godfrey, Hodgson, Tarca, Hamilton, \& Holmes, 2010). Penyedia informasi akuntansi merupakan manajemen entitas yang melaksanakan operasional entitas (agent) dan pengguna informasi akuntansi merupakan pemegang saham, kreditur, pajak, maupun pemangku kepentingan lainnya (principal). Principal menyewa jasa agent untuk mengelola dan melaporkan operasional entitas. Sehingga menimbulkan keadaan di mana agent mempunyai informasi yang lebih banyak tentang perusahaan dan prospek perusahaan dimasa yang akan datang dibandingkan dengan principal (Barus \& Setiawati, 2015).

Asimetris informasi antara agent yang menyusun laporan keuangan dan principal yang menggunakan informasi tersebut menimbulkan peluang terjadinya manajemen laba. Manajemen laba terjadi ketika agent menggunakan pertimbangan dalam pelaporan keuangan dan penataan transaksi untuk mengubah laporan keuangan menjadi menyesatkan beberapa pemangku kepentingan tentang keuangan yang berdasarkan kinerja perusahaan atau mempengaruhi hasil kontrak yang dibayarkan sesuai dengan pelaporan kinerja keuangan perusahaan. Manajemen laba dapat dianggap sebagai suatu tindakan normal untuk mengelola pendapatan, sehingga manajemen laba dapat bersifat bermanfaat, netral, atau merugikan. Untuk membatasi sifat tersebut, terbentuk standar akuntansi yang wajib digunakan oleh entitas dalam menyusun laporan keuangan. Standar tersebut merupakan jaminan bahwa informasi yang disajikan dapat diandalkan oleh pengguna laporan keuangan. Pihak yang mendapatkan keuntungan dari pemerataan laba adalah agent atau manajemen perusahaan. Metode pemerataan laba memiliki batasan yang tipis dengan pelaporan keuangan yang curang. Pemerataan laba akan berubah menjadi pelaporan keuangan yang curang jika memiliki tujuan untuk mempengaruhi pengambilan keputusan pengguna laporan keuangan. Keputusan yang dipengaruhi antara lain, menaikkan harga saham di bursa efek, mencapai target pendapatan yang ditetapkan, mengurangi pajak hingga mempertahankan atau meningkatkan jabatan dalam entitas. Sehingga SAK terus diperbaharui untuk membatasi manajemen laba yang dapat merugikan pengguna laporan keuangan

\section{METODE RISET}

Data sekunder dengan menggunakan laporan keuangan tiga perusahaan yang bergerak dalam sektor konstruksi. Data didapatkan dari lamaan BEI dengan kategori sektor Property, Real estate, Building Construction. Penulisan ini juga menggunakan data sekunder lain berupa studi kepustakaan 
dan penelitian sebelumnya. Studi kepustakaan berupa buku ilmiah, jurnal, dan penelusuran internet sebagai bahan referensi dalam pengerjaan penelitian ini.

Metode penelitian yang digunakan adalah kualitatif dengan cara mengevaluasi penerapan PSAK 72 pada perusahaan dalam sektor konstruksi. Penelitan Penerapan PSAK 72 akan dijelaskan secara deskriptif dan menggunakan simulasi berdasarkan laporan keuangan pada ketiga perusahaan yang telah dijadikan objek penelitian. Hasil dari penelitian berupa hasil analisis dari penerapan PSAK 72 laporan keuangan perusahaan yang telah ditetapkan sebagai objek penelitian. Penelitian menggunakan 3 perusahaan yang terdaftar dalam Bursa Efek Indonesia (BEI), terdaftar dalam sektor Property, Real estate, Building Construction, yaitu PT Wijaya Karya (Persero) Tbk, PT PP (Persero) Tbk, dan PT Waskita Karya (Persero) Tbk.

Metode Analisa data yang pertama adalah terkait 1) pengakuan pendapatan berdasarkan PSAK 72 (mengidentifikasi kontrak dengan pelanggan, mengidentifikasi kewajiban pelaksanaan dan penyelesaian kewajiban pelaksanaan), 2) pengukuran pendapatan kontrak jangka panjangn dengan 2 tahap yaitu menetukan harga transaksi dan mengalokasikan harga transaksi terhadap kewajiban pelaksanan, 3) penerapan pengakuan dan pengukuran PSAK 72 dengan membandingkan dengan pajak penghasilan final dan dampaknya atas manajemen laba

\section{HASIL PENELITIAN DAN PEMBAHASAN}

Ketiga perusahaan BUMN dalam penelitian ini adalah PT Wijaya Karya (Persero) Tbk, PT PP (Persero) Tbk, dan PT Waskita Karya (Persero) Tbk yang bergerak pada bidang konstruksi. Ketiga perusahaan merupakan milik negara yang memiliki usaha utama, yaitu jasa konstruksi, pembangunan, dan penjualan real estate. Pendapatan berdasarkan ketiga laporan keuangan perusahaan 2019, PSAK 34, PSAK 44, dan praktik bisnis pada umumnya, yaitu:

1. Pendapatan Kontrak Konstruksi

Praktik bisnis kontrak konstruksi secara umum yaitu, perusahaan menyediakan pembebasan tanah, material, jasa konstruksi, dan upah para pekerja konstruksi.

2. Pendapatan Kontrak Real estate

Praktik bisnis kontrak real estate secara umum yaitu, penjualan apartemen beserta tanah dimulai sejak perusahaan melakukan pembangunan apartemen.

Pendapatan dari kontrak konstruksi dan kontrak real estate akan diterapkan dalam PSAK 72 yang menggantikan PSAK 34 dan PSAK 44 yang telah digunakan sebelumnya. Penerapan PSAK 72 menggunakan lima model tahapan pada kedua kontrak. Berikut pembahasan penerapan PSAK 72 sebagai berikut: 
1. Identifikasi kontrak dengan pelanggan

Tabel 1: Syarat PSAK72 paragraf 09 dengan perusahaan sampel

\begin{tabular}{|c|c|c|}
\hline No & $\begin{array}{l}\text { Mengidentifikasi kontrak } \\
\text { PSAK } 72 \text { paragraf } 09\end{array}$ & $\begin{array}{l}\text { Kontrak konstruksi dan } \\
\text { kontrak real estate }\end{array}$ \\
\hline (b) & $\begin{array}{l}\text { para pihak dalam kontrak } \\
\text { telah menyetujui kontrak } \\
\text { (secara tertulis, lisan atau } \\
\text { sesuai dengan praktik bisnis } \\
\text { pada umumnya) dan } \\
\text { berkomitmen untuk } \\
\text { melaksanakan kewajiban } \\
\text { mereka masing-masing; }\end{array}$ & $\begin{array}{l}\text { Kontrak konstruksi disetujui oleh kedua belah pihak, yaitu pihak } \\
\text { pemberi tugas dan pihak pelaksana tugas. Untuk mengikatkan diri } \\
\text { dan menunjukkan komitmen atas kontrak diberlakukan tanda uang } \\
\text { jadi antara pihak satu ke pihak lainnya yaitu, uang muka dari } \\
\text { pemberi kerja. } \\
\text { Kontrak real estate disetujui oleh kedua belah pihak yaitu pihak } \\
\text { pengembang dan pihak pembeli. Untuk mengikatkan diri dan } \\
\text { menunjukkan komitmen atas kontrak diberlakukan uang muka dari } \\
\text { pelanggan dengan metode deposito yaitu, sebagai uang muka dari } \\
\text { pelanggan. } \\
\text { Hak setiap pihak dalam kontrak konstruksi meliputi perikatan } \\
\text { dana, persentase keuntungan dan pengembalian modal untuk } \\
\text { pelaksana tugas, pihak yang menyediakan material, tenaga kerja, } \\
\text { dan kebutuhan teknis lainnya, pihak pelaksana memberikan tenaga } \\
\text { kerja spesialis konstruksi, dan pembagian keuntungan atas } \\
\text { penjualan bangunan yang telah dibangun. Hak dan kewajiban } \\
\text { perusahaan dijelaskan dengan detail dalam kontrak. } \\
\text { Hak setiap pihak dalam kontrak real estate meliputi pihak penjual } \\
\text { wajib mengembangkan dan menjual real estate kepada pihak } \\
\text { pembeli dan pihak pembeli wajib membeli dari pihak penjual. Hak } \\
\text { dan kewajiban perusahaan dijelaskan dengan detail dalam kontrak. }\end{array}$ \\
\hline
\end{tabular}

Diasumsikan bahwa seluruh syarat terpenuhi dan terdapat kontrak dengan pelanggan. Kontrak dapat dikategorikan sebagai kontrak kombinasi jika terpenuhinya satu atau lebih syarat dalam PSAK 72: paragraf 17. Berikut hasil analisis kontrak kombinasi:

Tabel 2: Syarat PSAK72 paragraf 17 dengan perusahaan sampel

\begin{tabular}{|c|c|c|}
\hline No & $\begin{array}{c}\text { Kombinasi kontrak } \\
\text { PSAK } 72 \text { paragraf } 17\end{array}$ & $\begin{array}{l}\text { Kontrak konstruksi dan } \\
\text { kontrak real estate }\end{array}$ \\
\hline (a) & $\begin{array}{l}\text { kontrak dinegosiasikan sebagai } \\
\text { satu paket dengan tujuan } \\
\text { komersial tunggal; }\end{array}$ & $\begin{array}{l}\text { Kontrak konstruksi pada ketiga perusahaan merupakan kontrak } \\
\text { penyediaan jasa pembangunan dan pengadaan barang, yaitu } \\
\text { bahan material dan tenaga kerja. Kontrak konstruksi } \\
\text { dikategorikan sebagai kontrak yang dinegosiasikan sebagai satu } \\
\text { paket dengan tujuan komersial tunggal. } \\
\text { Kontrak real estate pada ketiga perusahaan meliputi } \\
\text { pengembangan dan penjualan tanah beserta bangunan. Di mana } \\
\text { bangunan tersebut merupakan hasil dari jasa pembangunan, } \\
\text { pengadaan bahan material, dan tenaga kerja. Kontrak real estate } \\
\text { dikategorikan sebagai kontrak yang dinegosiasikan sebagai satu } \\
\text { paket dengan tujuan komersial tunggal. }\end{array}$ \\
\hline (b) & $\begin{array}{l}\text { jumlah imbalan yang dibayarkan } \\
\text { dalam satu kontrak bergantung } \\
\text { pada harga atau pelaksanaan dari } \\
\text { kontrak lain; atau }\end{array}$ & $\begin{array}{l}\text { Jumlah imbalan dalam kontrak konstruksi dan kontrak real } \\
\text { estate tersebut hanya bergantung pada satu harga kontrak yang } \\
\text { tertera dalam kontrak. }\end{array}$ \\
\hline (c) & $\begin{array}{l}\text { barang atau jasa yang dijanjikan } \\
\text { dalam kontrak (atau beberapa } \\
\text { barang atau jasa yang dijanjikan } \\
\text { dalam setiap } \\
\text { merupakan } \\
\text { pelaksanaan tunggal. }\end{array}$ & $\begin{array}{l}\text { Kontrak konstruksi dan kontrak real estate merupakan } \\
\text { kewajiban pelaksanaan tunggal yang meliputi gabungan } \\
\text { penyediaan jasa pembangunan, pengadaan bahan material dan } \\
\text { tenaga kerja. }\end{array}$ \\
\hline
\end{tabular}

Sumber:Hasil Olah Data Peneliti 
Berdasarkan tabel 1 dan 2 dinyatakan bahwa kontrak konstruksi dan kontrak real estate terdapat kontrak dengan pelanggan dan kontrak kombinasian. Pengerjaan kontrak yang bersifat jangka panjang seperti kontrak konstruksi dan kontrak real estate dapat dilakukan modifikasi. Modifikasi kontrak dalam ketiga perusahaan tidak dapat diketahui dari laporan keuangan tahun 2019. Atas keterbatasan penelitian tersebut, diasumsikan bahwa kontrak pada ketiga perusahaan tidak dimodifikasi sampai akhir tahun 2019.

2. Identifikasi kewajiban pelaksanaan

Kontrak menjelaskan bagaimana penilaian barang atau jasa yang diberikan kepada pelanggan dan identifikasi kewajiban pelaksanaan yang diberikan kepada pelanggan. Penilaian tersebut bergantung pada penentuan apakah barang atau jasa dapat dibedakan yang telah memenuhi syarat dalam PSAK72: paragraf 27. Berikut hasil analisis barang atau jasa dapat dibedakan:

Tabel 3: Syarat PSAK72 paragraf 27 dengan perusahaan sampel

\begin{tabular}{|c|c|c|}
\hline No & $\begin{array}{l}\text { Barang atau jasa dapat } \\
\text { dibedakan } \\
\text { PSAK } 72 \text { paragraf } 27\end{array}$ & $\begin{array}{l}\text { Kontrak konstruksi dan } \\
\text { kontrak real estate }\end{array}$ \\
\hline (a) & $\begin{array}{l}\text { pelanggan memperoleh manfaat } \\
\text { dari barang atau jasa baik barang } \\
\text { atau jasa itu sendiri atau bersama } \\
\text { dengan sumber daya lain yang } \\
\text { siap tersedia kepada pelanggan; } \\
\text { dan }\end{array}$ & $\begin{array}{l}\text { Kontrak konstruksi dan kontrak real estate tidak memberikan } \\
\text { manfaat karena pelanggan belum bisa menggunakan, } \\
\text { mengonsumsi atau mengusai barang atau jasa dari kontrak } \\
\text { tersebut karena proses konstruksi yang pengerjaannya masih } \\
\text { berjalan dan bersifat jangka panjang }\end{array}$ \\
\hline (b) & $\begin{array}{l}\text { janji entitas untuk mengalihkan } \\
\text { barang atau jasa kepada } \\
\text { pelanggan dapat diidentifikasi } \\
\text { secara terpisah dari janji lain } \\
\text { dalam kontrak }\end{array}$ & $\begin{array}{l}\text { Pengalihan barang atau jasa dalam kontrak konstruksi dan } \\
\text { kontrak real estate selama masa pengerjaan tidak bisa dibedakan } \\
\text { karena masih dalam tahap penyelesaian. Input berupa jasa, bahan } \\
\text { material, dan upah pekerja namun output berupa bangunan dan } \\
\text { real estate yang bersifat kombinasi sehingga tidak dapat } \\
\text { diidentifikasikan secara terpisah. }\end{array}$ \\
\hline
\end{tabular}

Berdasarkan tabel 3 dinyatakan bahwa kontrak konstruksi dan kontrak real estate tidak memenuhi syarat dan dikategorikan sebagai barang atau jasa bersifat tidak bisa dibedakan. Selanjutnya mengidentifikasi kewajiban pelaksanaan setiap janji pengalihan aset atau barang kepada pelanggan. Perusahaan mencatat seluruh barang dan jasa di dalam kontrak sebagai kewajiban pelaksanaan tunggal.

3. Penyelesaian kewajiban pelaksanaan

Kewajiban pelaksanaan ditentukan pada saat pembentukan kontrak. Terdapat dua metode dalam kewajiban pelaksanaan, yaitu penyelesaian sepanjang waktu atau penyelesaian pada waktu tertentu. Jika satu atau lebih dari kriteria pada PSAK 72: paragraf 35 terpenuhi, maka kewajiban pelaksanaan dapat menggunakan metode penyelesaian sepanjang waktu. Pada tabel 4 adalah hasil analisis kewajiban pelaksanaan.

Berdasarkan tabel 4, kontrak konstruksi memenuhi syarat paragraf 35(b) dan 35(c). Sedangkan kontrak real estate tidak dapat memenuhi syarat paragraf 35. Sehingga kontrak konstruksi estat menggunakan metode kewajiban pelaksanaan sepanjang waktu, namun kontrak real estate menggunakan metode pada waktu tertentu. Sehingga kewajiban pelaksanaan kontrak konstruksi saat 
melakukan penerapan PSAK 34 tidak memiliki perbedaan dalam mengakui pendapatan dengan penerapan PSAK 72. Berbeda dengan kewajiban pelaksanaan kontrak real estate saat melakukan penerapan PSAK 44 memiliki perbedaan dalam mengakui pendapatan dengan penerapan PSAK 72 karena pengakuan pendapatan berubah yang sebelumnya dapat diakui sepanjang waktu menjadi pada waktu tertentu saat penyerahan apartemen diberikan kepada pelanggan

Tabel 4: Syarat PSAK72 paragraf 35 dengan perusahaan sampel

\begin{tabular}{|c|c|c|}
\hline No & $\begin{array}{c}\text { Kewajiban pelaksanaan } \\
\text { PSAK } 72 \text { paragraf } 35\end{array}$ & $\begin{array}{l}\text { Kontrak konstruksi dan } \\
\text { kontrak real estate }\end{array}$ \\
\hline (a) & $\begin{array}{l}\text { pelanggan secara simultan } \\
\text { menerima dan mengonsumsi } \\
\text { manfaat yang disediakan oleh } \\
\text { kinerja entitas saat entitas } \\
\text { melaksanakan kewajiban } \\
\text { pelaksanaannya tersebut; }\end{array}$ & $\begin{array}{l}\text { Pelanggan belum bisa menerima dan mengonsumsi manfaat atas } \\
\text { kinerja entitas saat melakukan kontrak konstruksi dan kontrak } \\
\text { real estate karena gedung maupun tanah masih belum bisa } \\
\text { digunakan oleh pelanggan. }\end{array}$ \\
\hline & & $\begin{array}{l}\text { Kontrak konstruksi menciptakan aset berupa bangunan dalam } \\
\text { proses yang dikendalikan oleh pelanggan sebagai aset yang } \\
\text { ditingkatkan dari tanah menjadi tanah dengan bangunan. }\end{array}$ \\
\hline (b) & $\begin{array}{l}\text { meningkatkan aset (sebagal } \\
\text { contoh, pekerjaan dalam proses) } \\
\text { yang dikendalikan pelanggan } \\
\text { sebagai aset yang diciptakan atau } \\
\text { ditingkatkan; atau }\end{array}$ & $\begin{array}{l}\text { Kontrak real estate tidak menciptakan aset berupa bangunan } \\
\text { dalam proses yang dikendalikan oleh pelanggan karena belum } \\
\text { ada penyerahan barang dan jasa kepada pelanggan selama proses } \\
\text { konstruksi berjalan. Penyerahan pengendalian aset dilakukan saat } \\
\text { seluruh pembangunan selesai atau biasa disebut sebagai serah } \\
\text { terima kunci kepada pelanggan. }\end{array}$ \\
\hline \multirow[t]{2}{*}{ (c) } & \multirow{2}{*}{$\begin{array}{l}\text { kinerja entitas tidak menciptakan } \\
\text { suatu aset dengan penggunaan } \\
\text { alternatif terhadap entitas dan } \\
\text { entitas memiliki hak atas } \\
\text { pembayaran yang dapat } \\
\text { dipaksakan atas kinerja yang } \\
\text { telah diselesaikan sampai saat } \\
\text { ini. }\end{array}$} & $\begin{array}{l}\text { Kontrak real estate tidak menciptakan aset berupa bangunan } \\
\text { dalam proses yang dikendalikan oleh pelanggan karena belum } \\
\text { ada penyerahan barang dan jasa kepada pelanggan selama proses } \\
\text { konstruksi berjalan. Penyerahan pengendalian aset dilakukan saat } \\
\text { seluruh pembangunan selesai atau biasa disebut sebagai serah } \\
\text { terima kunci kepada pelanggan. }\end{array}$ \\
\hline & & $\begin{array}{l}\text { Aset yang tercipta dari kontrak real estate tidak memiliki } \\
\text { penggunaan alternatif karena bangunan apartemen sesuai dengan } \\
\text { kontrak dan entitas berhak atas pembayaran jika sudah serah } \\
\text { terima kunci kepada pelanggan. }\end{array}$ \\
\hline
\end{tabular}

Sumber:Hasil Olah Data Peneliti

4. Menentukan harga transaksi

Penentuan harga transaksi kontrak konstruksi berdasarkan praktik bisnis secara umum meliputi nilai kontrak, syarat kontrak, dan denda. Penentuan harga transaksi kontrak penjualan real estate berdasarkan praktik bisnis secara umum meliputi harga bangunan, harga tanah, syarat kontrak, suku bunga, dan denda. Imbalan variabel kontrak konstruksi bersifat jumlah yang paling mungkin terjadi atas imbalan, hal tersebut berdasarkan bahwa kontrak konstruksi memiliki hak untuk memaksakan imbalan saat pengerjaan berhasil terpenuhi atau saat pengerjaan tertunda di mana akan dibayar sesuai dengan persentase penyelesaian. Sedangkan kontrak real estate bersifat dapat diperkirakan, hal tersebut berdasarkan bahwa perusahaan sudah memiliki estimasi imbalan yang akan naik setiap periode penjualan apartemen, sehingga pendapatan akan dihitung secara rata-rata dari nilai ekspektasi penjualan. 
5. Mengalokasikan harga transaksi terhadap kewajiban pelaksanaan

Berdasarkan analisis sebelumnya, dinyatakan bahwa kontrak konstruksi menggunakan metode alokasi harga transaksi sepanjang waktu (overtime) dan kontrak real estate menggunakan metode alokasi harga transaksi pada waktu tertentu (at point in time). Pengalokasian terhadap kontrak konstruksi atas kewajiban pelaksanaan dilakukan sepanjang waktu dengan perhitungan berdasarkan berita acara penyelesaian pekerjaan konstruksi yang dinilai dari pihak eksternal hingga pekerjaan selesai. Pengakuan pendapatan kontrak real estate sebelumnya menggunakan metode yang sama dengan kontrak konstruksi, namun kontrak konstruksi tidak dapat memenuhi syarat terdapat dalam paragraf 35. Tidak terpenuhinya syarat tersebut karena kontrak real estate selama masa pembangunan belum melakukan pemindahan pengendalian aset kepada pelanggan. Sehingga kontrak real estate yang pengalokasian harga transaksi dilakukan sepanjang waktu kemudian berubah menjadi pada waktu tertentu yaitu saat pemindahan pengendalian aset kepada pelanggan. Pemindahan pengendalian aset ditandai dengan penyelesaian seluruh pembangunan dan pengembangan dan penyerahan kunci kepada pelanggan. Oleh karena itu, dapat disimpulkan bahwa pendapatan dari kontrak konstruksi tidak memiliki perbedaan dengan metode pengakuan pendapatan yang digunakan sebelumnya, namun dan kontrak real estate memiliki perbedaan pengakuan pendapatan dibandingkan dengan sebelumnya.

Penerapan pengakuan pendapatan PSAK 72 terhadap pajak penghasilan final dan manajemen laba pada perusahaan konstruksi adalah sebagai berikut:

1. Pajak penghasilan final pada perusahaan konstruksi

Pengakuan pendapatan PSAK 72 tidak memiliki perbedaan dengan pengakuan pendapatan PSAK 34, namun perbedaan terjadi pada PSAK 44. Pengakuan pendapatan real estate berdasarkan PSAK 72 dan pajak memiliki perbedaan yang akan menyebabkan laporan keuangan fiskal dengan laporan keuangan perusahaan akan memiliki perbedaan. Perbedaan tersebut terjadi karena pajak mengakui pendapatan dan mengenakan pajak pada saat penerimaan uang, sedangkan PSAK 72 mengakui pendapatan saat serah terima aset kepada pelanggan. Hal tersebut merupakan tantangan tersendiri bagi perusahaan yang bergerak dalam bidang real estate, terutama akuntan manajemen dalam menjelaskan perbedaan kepada pemegang saham dan pihak kepentingan lainnya dalam pengambilan keputusan. Perbedaan penilaian pendapatan pada PSAK 72 mengacu pada estimasi hak atas imbalan kepada perusahaan, sedangkan dalam PPh final berdasarkan harga perolehan. Sebagai kesimpulan PSAK 72 tidak mengubah pajak penghasilan final atas jasa konstruksi, namun mengubah pajak atas penjualan apartemen karena berbeda pada pengakuan pendapatannya. Perbedaan juga terletak pada penilaian pendapatan di mana pajak penghasilan final menggunakan harga perolehan, sedangkan PSAK 72 menggunakan harga estimasi perolehan.

2. Manajemen laba pada perusahaan konstruksi

Perbedaan pengakuan tersebut akan mengurangi pendapatan atas penjualan apartemen yang belum dilakukan serah terima. Hal tersebut menurunkan pendapatan atas penjualan apartemen sehingga 
kinerja perusahaan akan berkurang. Penurunan laba perusahaan akan berdampak pada strategi perusahaan dalam melakukan manajemen laba. Perusahaan terdorong untuk melakukan manajemen laba karena tidak ada laba selama proses pembangunan dan pengembangan real estate. Hal tersebut mendorong perusahaan harus berpikir kreatif sebagai contoh membuat diversifikasi usaha atau melakukan manajemen laba agar laporan keuangan terlihat "baik". Manajemen laba dilakukan perusahaan untuk menjaga laba perusahaan tidak berpengaruh signifikan. Namun manajemen laba terletak dalam "zona abu-abu" di mana dapat dinyatakan sebagai pembuatan laporan keuangan yang curang jika tidak mencerminkan keadaan yang sebenarnya dan mempengaruhi pembuatan keputusan pemangku kepentingan.

Pelaksanaan manajemen laba PSAK 72 dibutuhkan untuk memperjelas batasan dalam memberikan informasi yang sesuai dengan keadaan dengan memberikan lima tahapan model dalam pengakuan pendapatan dibandingkan dengan PSAK 34 dan PSAK 44 dalam mengakui pendapatan. PSAK 72 mengatur bahwa pendapatan hanya bisa jika melakukan kontrak dengan pelanggan. Jika sebelumnya PSAK 34 dan PSAK 44 dilihat berdasarkan rule based, namun PSAK 72 berdasarkan principal based. Di mana PSAK 34 dan PSAK 44 melihat dari aktivitas melakukan pendapatan, sedangkan PSAK 72 melihat berdasarkan hasil evaluasi kontrak-kontrak dengan pelanggan. Hal tersebut akan berdampak dalam memberikan informasi yang relevan dan andal mengenai pendapatan dalam pelaporan laporan keuangan. Sehingga penerapan PSAK 72 dapat memperjelas batasan perusahaan dalam melakukan manajemen laba.

\section{KESIMPULAN DAN SARAN}

Berdasarkan hasil analisis dan penelitian yang telah dilakukan dapat disimpulkan sebagai berikut:

1. Dampak penerapan pengakuan pendapatan PSAK 72 terhadap kontrak konstruksi menyatakan bahwa kontrak konstruksi merupakan kontrak dengan pelanggan, kontrak merupakan kewajiban tunggal, dan pelaksanaan kewajiban menggunakan overtime. Dampak penerapan pengakuan pendapatan PSAK 72 terhadap kontrak real estate menyatakan bahwa kontrak konstruksi merupakan kontrak dengan pelanggan dan kontrak merupakan kewajiban tunggal. Pelaksaan kewajiban berubah dari metode sepanjang waktu menjadi pada waktu tertentu saat penyelesaian pembangunan dan penyerahan kunci kepada pelanggan.

2. Dampak penerapan pengukuran pendapatan PSAK 72 terhadap kontrak konstruksi menyatakan bahwa kontrak diukur berdasarkan jumlah paling mungkin terjadi. Pelaksanaan kewajiban dilakukan sepanjang waktu dengan metode output. Dampak penerapan pengukuran pendapatan PSAK 72 terhadap kontrak real estate menyatakan bahwa kontrak diukur berdasarkan dapat diperkirakan. Pelaksanaan kewajiban dilakukan pada waktu tertentu pada saat serah terima kunci kepada pelanggan. 
3. Penerapan PSAK 72 terhadap pajak penghasilan konstruksi tidak memiliki dampak karena pengakuan pendapatan masih menggunakan overtime. Penerapan PSAK 72 terhadap pajak penghasilan real estate memiliki dampak perubahan pengenaan pajak yang sebelumnya menggunakan overtime menjadi at point in time pada saat penyerahan apartemen. Pengukuran pendapatan PSAK 72 atas pajak penghasilan kedua pendapatan menggunakan harga estimasi sedangkan sebelumnya menggunakan harga perolehan.

Penelitian ini memiliki keterbatasan yang dimiliki dan dialami oleh peneliti selama pengerjaan hingga rampungnya penelitian ini, yaitu:

1. Penelitian menggunakan perusahaan konstruksi dengan kategori BUMN yang terdaftar di BEI pada akhir tahun 2019, sehingga hasil penelitian belum dapat digeneralisasikan.

2. Jumlah perusahaan sampel dan jenis kontrak dengan pelanggan dirasa masih kurang untuk mewakili perusahaan yang mulai mengadopsi

3. Penelitian menggunakan data berdasarkan laporan keuangan ketiga perusahaan pada akhir tahun 2019, sehingga belum menunjukkan dampak penerapan PSAK72.

4. Informasi mengenai kontrak konstruksi dan kontrak real estate pada ketiga perusahaan menggunakan asumsi berdasarkan praktik bisnis pada umumnya.

5. Pajak penghasilan final dan manajemen laba dalam penelitian ini merupakan pra pengujian dikarenakan belum adanya pajak penghasilan dan manajemen laba yang mengacu pada PSAK72.

6. Penelitian ini tidak membahas terkait penyajian dan pengungkapan penerapan PSAK 72 karena perusahaan masih dalam proses penerapan PSAK 72.

Saran dari peneliti untuk penelitian selanjutnya, yaitu:

1. Meneliti sebelum dan sesudah penerapan PSAK72.

2. Penelitian menggunakan industri lain yang berdampak signifikan yang disebutkan oleh PWC, yaitu industri telekomunikasi, otomotif, manufaktur, real estate, barang retail, dan barang konsumsi.

3. Memperluas ruang lingkup penyajian dan pengungkapan yang belum dibahas pada penelitian.

4. Meneliti dampak PSAK72 dengan pajak penghasilan final dan manajemen laba. 


\section{DAFTAR PUSTAKA}

Barus, A. C., \& Setiawati, K. (2015). Pengaruh Asimetri Informasi, Mekanisme Corporate Governance, Dan Beban Pajak Tangguhan Terhadap Manajemen Laba. Jurnal Wira Ekonomi Mikroskil.

Bernoully, M., \& Wondabio, L. S. (2018). Impact of Implementation of IFRS 15 on the Financial Statements of Telecommunication Company (Case Study of PT XYZ). Advances in Economics, Business and Management Research, volume 89.

Deloitte. (2020). Revenue recognition: Deloitte. Diambil kembali dari Deloitte Web Site: https://www.iasplus.com/en/projects/completed/revenue/revenue-recognition

Direktorat Jenderal Pajak. (2020). PPh Pasal 23/26. Diambil kembali dari DJP Web Site: https://www.pajak.go.id/id/pph-pasal-

2326\#: :text=Saat\%20terutangnya\%20Pajak\%20Penghasilan\%20Pasal,jasa\%20manajemen\% 20atau\%20jasa\%20lainnya).

Ervinda, M. Y., \& Ridho, M. H. (2020). Dampak IFRS 15 Bagi Laporan Keuangan Perusahaan Konstruksi. Keberlanjutan : Jurnal Manajemen dan Jurnal Akuntansi, Volume 5 (1) 2020, 3850.

Fivna, A. (2011). Penggunaan Simulasi Monte Carlo Untuk Menentukan Nilai Outcome Pada Pengambilan Keputusan :Studi Kasus Pengambilan Keputusan pada Toko NAFC Collection.

Gani, I., \& Amalia, S. (2018). Alat Analisis Data.

Godfrey, J., Hodgson, A., Tarca, A., Hamilton, J., \& Holmes, S. (2010). Accounting Theory. Wiley.

Hidayat, A. (2017). Penjelasan Teknik Purposive Sampling Lengkap Detail. Diambil kembali dari Statistikian Web Site: https://www.statistikian.com/2017/06/penjelasan-teknik-purposivesampling.html\#: : :text=Purposive\%20sampling\%20adalah\%20salah\%20satu,diharapkan\%20d apat\%20menjawab\%20permasalahan\%20penelitian.\&text=Baca\%20juga\%3A\%20Menghitun g\%20Besar\%20sampel\%20Penelitian

Ikatan Akuntan Indonesia. (2018). Standar Akuntansi Keuangan.

Ikatan Akuntan Indonesia. (2020). Pengesahan Psak 71, Psak 72, dan Amendemen PSAK 62. Diambil kembali dari IAI GLOBAL Web Site: http://iaiglobal.or.id/v03/berita-kegiatan/detailberita1011-pengesahan-psak-71-psak-72-dan-amendemen-psak-62

Ikatan Akuntan Indonesia. (2020). Tentang Kami: Standar Akuntansi Keuangan (SAK). Diambil kembali dari Standar Akuntansi Keuangan: http://iaiglobal.or.id/v03/standar-akuntansikeuangan/tentang-kami

Ikatan Akuntan Indonesia. (2020). Undangan Public Hearing Exposure Draft Amandemen Psak 62, Ed Psak 72, Ed ISAK 32. Diambil kembali dari IAI GLOBAL: http://iaiglobal.or.id/v03/beritakegiatan/detailberita-963-undangan-public-hearing-exposure-draf. 
Institut Akuntansi Manajemen Indonesia. (2020). Gap Yang Semakin Melebar Antara Standar Akuntansi Berlaku Efektif 1 Januari 2020 dengan Aturan Pajak.

Jayani, D. H. (2019). Terbesar di Era Jokowi, Anggaran Infrastruktur Rp 419,2 Triliun di RAPBN 2020.
Diambil
kembali
dari
Databoks
Web
Site:

https://databoks.katadata.co.id/datapublish/2019/08/19/terbesar-di-era-jokowi-anggaraninfrastruktur-rp-4192-triliun-di-rapbn-2020

Kementerian Keuangan Republik Indonesia Direktorat Jenderal Pajak. (2013). Undang-Undang KUP dan Peraturan Pelaksanaannya.

Marco Tutino, C. R. (2019). Does the IFRS 15 impact earnings management? Initial evidence from Italian listed companies. African Journal of Business Management.

Novius, A. (2011). Earning Management Dalam Penawaran Saham Perdana Perusahaan Manufaktur Di Bursa Efek Indonesia. Jurusan Akuntansi Fakultas Ekonomi dan Ilmu Sosial UIN Suska Riau.

PT PP (Persero) Tbk. (2016). About Us: PT PP (Persero) Tbk. Diambil kembali dari PT PP (Persero) Tbk Web Site: https://www.ptpp.co.id/about/our-values

PT Wijaya Karya (Persero) Tbk. (2020). Komitmen: PT Wijaya Karya (Persero) Tbk. Diambil kembali dari PT Wijaya Karya (Persero) Tbk. Web Site: https://www.wika.co.id/id/pages/commitment

PT. Waskita Karya (Persero) Tbk. (2020). Budaya Perusahaan: PT. Waskita Karya (Persero) Tbk. Diambil kembali dari PT. Waskita Karya (Persero) Tbk Web Site: https://www.waskita.co.id/pages/about/corporate-culture?lang=id

PwC. (2017). 10 Minutes on PSAK 72.

Samosir, R. T. (2020). Analisis Pengakuan Pendapatan Pada Penjualan Apartemen di PT XYZ.

Santosa, P. (2015). Metode Penelitian Sastra. Badan Pengembangan dan Pembinaan Bahasa Kementerian Pendidikan dan Kebudayaan.

The International Financial Reporting Standards Foundation. (2017). About Us: IFRS Foundation. Diambil kembali dari IFRS Foundation Web Site: https://www.ifrs.org/about-us/who-weare/\#about-us

The International Financial Reporting Standards Foundation. (2017). Why global accounting standards?: IFRS Foundation. Diambil kembali dari IFRS Foundation Web Site: https://www.ifrs.org/use-around-the-world/why-global-accounting-standards/

Veronica, Lestari, U. P., \& Metekohy, E. Y. (2019). Analisis Dampak Penerapan Pengakuan Pendapatan Berdasarkan PSAK 72 Terhadap Kinerja Keuangan Perusahaan Real estate di Indonesia yang Terdaftar di Bursa Efek Indonesia Tahun 2018. 10th Industrial Research Workshop and National Seminar. 
Adella, M., Dewi, N.S., \& Ahalik, A. (2021). Analisis Penerapan Pengakuan Pendapatan ...

Violencia C.I. Kondoy, G. B. (2016). Analisis Penerapan Pajak Penghasilan Jasa. Jurnal Berkala Ilmiah Efisiensi.

Wisnantiasri, S. N. (2018). Pengaruh PSAK 72: Pendapatan Dari Kontrak Dengan Pelanggan Terhadap Shareholder Value (Studi pada Perusahaan Sektor Property, Real estate and Building Construction). Widyakala Volume 5 No. 1. 